Document downloaded from:

http://hdl.handle.net/10251/142276

This paper must be cited as:

Gonzalez-Camejo, J.; Jiménez Benítez, AL.; Ruano García, MV.; Robles Martínez, A.; Barat, R.; Ferrer, J. (01-0). Optimising an outdoor membrane photobioreactor for tertiary sewage treatment. Journal of Environmental Management. 245:76-85. https://doi.org/10.1016/j.jenvman.2019.05.010

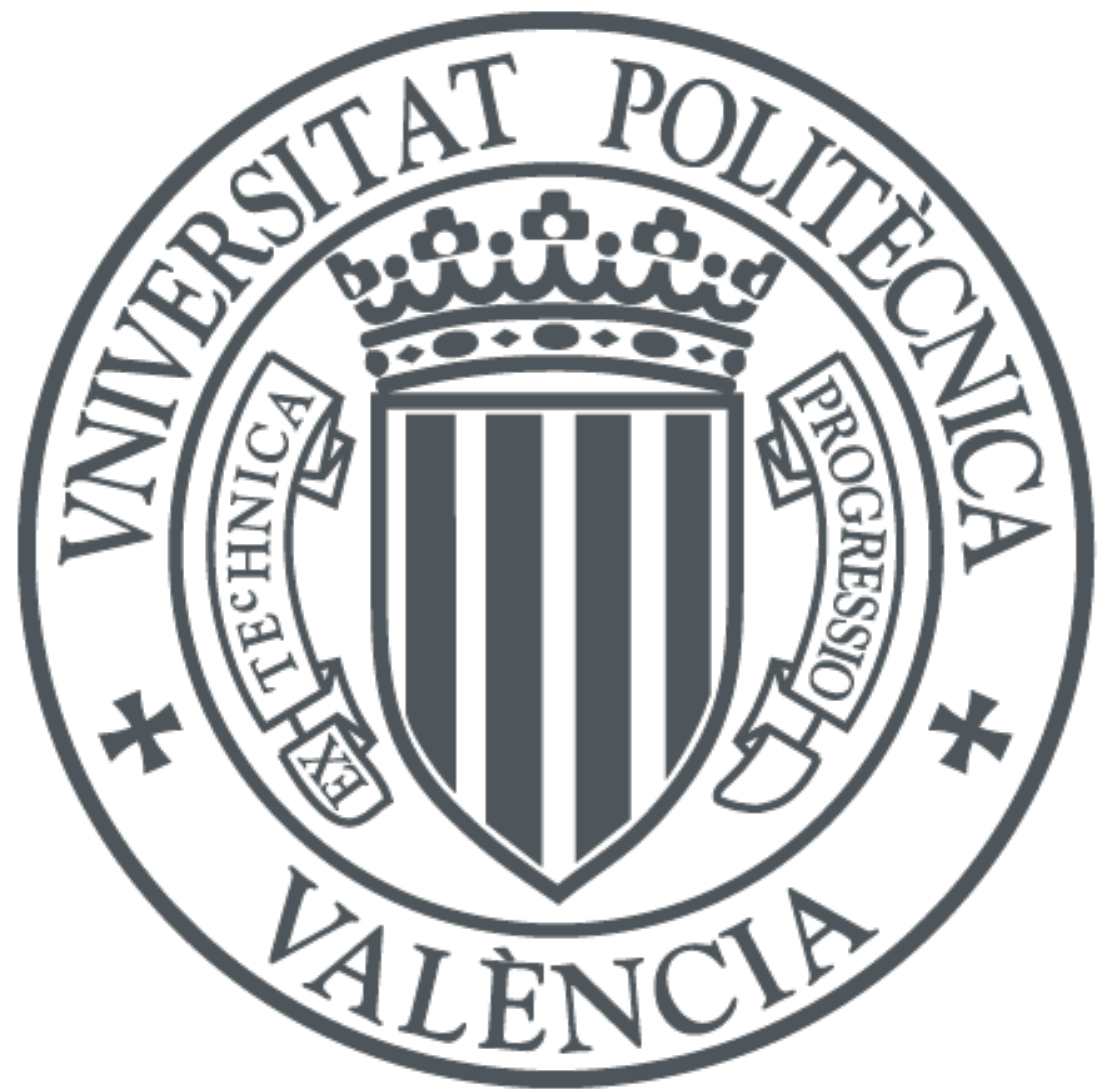

The final publication is available at

https://doi.org/10.1016/j.jenvman.2019.05.010

Copyright Elsevier

Additional Information 


\title{
Optimising an outdoor membrane photobioreactor for tertiary sewage treatment
}

J. González-Camejo ${ }^{1}$, A. Jiménez-Benítez ${ }^{1}$, M.V. Ruano ${ }^{2}$, A. Robles ${ }^{2}$, R. Barat ${ }^{\text {* }}$ and J. Ferrer ${ }^{1}$.

${ }^{1}$ CALAGUA - Unidad Mixta UV-UPV, Institut Universitari d'Investigació d'Enginyeria de l'Aigua i Medi Ambient-IIAMA, Universitat Politècnica de València, Camí de Vera s/n, 46022 Valencia, Spain.

${ }^{2} C A L A G U A$ - Unidad Mixta UV-UPV, Departament d'Enginyeria Química, Universitat de València, Avinguda de la Universitat s/n, 46100 Burjassot, Valencia, Spain.

*Corresponding author

Email address rababa@dihma.upv.es (R. Barat)

\begin{abstract}
The operation of an outdoor membrane photobioreactor plant which treated the effluent of an anaerobic membrane bioreactor was optimised. Biomass retention times of 4.5, 6, and 9 days were tested. At a biomass retention time of 4.5 days, maximum nitrogen recovery rate:light irradiance ratios, photosynthetic efficiencies and carbon biofixations of $51.7 \pm 14.3 \mathrm{mg} \mathrm{N} \cdot \mathrm{mol}^{-1}, 4.4 \pm 1.6 \%$ and $0.50 \pm 0.05 \mathrm{~kg} \mathrm{CO} \cdot \mathrm{m}^{3}$ influent, respectively, were attained. Minimum membrane fouling rates were achieved when operating at the shortest biomass retention time because of the lower solid concentration and the negligible amount of cyanobacteria and protozoa.

Hydraulic retention times of $3.5,2$, and 1.5 days were tested at the optimum biomass retention times of 4.5 days under non-nutrient limited conditions, showing no significant differences in the nutrient recovery rates, photosynthetic efficiencies and membrane fouling rates. However, nitrogen recovery rate:light irradiance ratios and photosynthetic efficiency significantly decreased when hydraulic retention time was
\end{abstract}


further shortened to 1 day, probably due to a rise in the substrate turbidity which reduced the light availability in the culture. Optimal carbon biofixations and theoretical energy recoveries from the biomass were obtained at hydraulic retention time of 3.5 days, which accounted for $0.55 \pm 0.05 \mathrm{~kg} \mathrm{CO} \cdot \mathrm{m}^{-3}$ influent and $0.443 \pm 0.103 \mathrm{kWh} \cdot \mathrm{m}^{-}$ ${ }^{3}$ influent, respectively.

Keywords: hollow-fibre membrane; membrane photobioreactor; microalgae cultivation; nutrient recovery; outdoor; photosynthetic efficiency.

\section{Introduction}

Wastewater treatment has played a key role in the development of human activities since the direct discharge of wastewaters to the environment without the appropriate treatment can imply a variety of pollution problems (Gonçalves et al., 2017) such as eutrophication, which can produce water quality losses and health risks (Guldhe et al., 2017). However, classical wastewater treatment plants (WWTPs) usually implies huge energy demands (Udaiyappan et al., 2017) and nutrient losses (Acién et al., 2016). On the other hand, water resource recovery facilities (WRRFs) use wastewater as a source of energy, nutrients and reclaimed water.

Membrane photobioreactor (MPBR) technology (which is the combination of membrane and microalgae cultivation) emerges as a suitable option within these novel WRRFs (Seco et al., 2018). Microalgae are able to efficiently reduce the nutrient load from wastewater while obtaining valuable microalgae biomass that can be anaerobically digested to produce biogas (Acién et al., 2016; Guldhe et al., 2017). The nutrient content in both the effluent of the anaerobic digestion and the digestate can be recovered for nutrient valorisation. In addition, the membrane filtration of the microalgae culture 
obtains a high-quality permeate in terms of suspended solids and pathogens, thus being a source of reclaimed water (Seco et al., 2018).

The filtration of microalgae also allows operating at shorter hydraulic retention times (HRTs) and longer biomass retention times (BRTs), enabling to recover large quantities of nutrients without washing out the microalgae culture (Gao et al., 2019). This can improve the microalgae performance while increasing the nutrient load to the system which would reduce the large areas of land that are needed for microalgae cultivation (Acién et al., 2016). By way of example, Bilad et al. (2014) reported in lab conditions 9fold higher microalgae biomass productivity than a PBR system when HRT and BRT were decoupled by membrane filtration. On the other hand, a previous study in outdoor conditions (González-Camejo et al., 2018a) reported double biomass productivity, 3.8fold higher nitrogen and phosphorus recovery rates in an MPBR system in comparison with a PBR system. The area of land required for the microalgae cultivation was 3.2fold lower.

When operating membrane-based systems, fouling is a major concern that must be considered (Robles et al., 2013; Gong et al., 2019) especially in microalgae cultivation systems (Wang et al., 2019). Fouling occurs when microalgae cells, their secretions and the cell debris accumulate on the membrane surface and inside the pores, reducing its permeability because of the cake-layer formation and the partial block of the membrane pores (Zhang and $\mathrm{Fu}, 2018$ ), which increases the energy consumption of the process (Wang et al., 2019). The cake layer mainly produces reversible fouling and can be removed by physical means such as gas-assisted membrane scouring and/or backwashing (Gong et al., 2019). On the other hand, cell debris retention in the pores is the major cause of irreversible fouling, which can only be removed by chemical reagents (Porcelli and Judd, 2010), determining the membrane lifetime (Zhang and Fu, 
2018). The performance of the filtration process in this type of system therefore has to be adequately assessed in order to achieve the most optimal microalgae cultivation process.

Several authors have studied the optimum operating ranges of BRT and HRT for labscale MPBR systems (Gao et al., 2018; Luo et al., 2018; Xu et al., 2015). However, outdoor microalgae cultivation from sewage is affected by environmental conditions in many different ways, such as the variable solar irradiance, ambient temperature and nutrient loads (Foladori et al., 2018; González-Camejo et al., 2018a). In fact, Van den Hende et al. (2014) reported under outdoor conditions a reduction of the nutrient recovery efficiency with a factor of 1-3 and with a factor of 10-13 in the case of biomass productivity. Hence, it is essential to optimise the microalgae cultivation performance to make the process feasible at large scale (Nayak et al., 2018).

The effect of several design factors such as the culture recirculation mode and the nonphotic volume of the MPBR plant of this study has been previously evaluated (see Table 1). These previous studies (González-Camejo et al., 2018a; Viruela et al., 2018) reported the outdoor microalgae performance not only at different BRT and HRT but also within variable operating/design conditions. Thus, this effect of BRT and HRT on process performance was not isolated. For instance, the decline in the MPBR performance reported by Viruela et al. (2018) when decreasing the BRT from 4.5 to 9 days (Table 1) was also highly influenced by a fall in solar irradiance and temperature. In addition, the results obtained by González-Camejo et al. (2018a) at BRT of 4.5 days and different HRTs (Table 1) were influenced by periods of nutrient limitation due to a significant reduction in the influent nutrient load and also by periods of temperature peaks. Thus, optimal BRT and HRT must be evaluated under nutrient-replete conditions (González-Camejo et al., 2019) and optimal design and operating conditions. Moreover, 
membrane fouling has not been previously assessed in this MPBR system, which would finally determine the technical and economic feasibility of the treatment process.

Table 1. Summary of the results obtained in previous studies

\begin{tabular}{|c|c|c|c|c|c|}
\hline \multirow{2}{*}{$\begin{array}{l}\text { Type of } \\
\text { reactor }\end{array}$} & \multirow{2}{*}{$\begin{array}{l}\text { Parameter } \\
\text { evaluated }\end{array}$} & \multicolumn{3}{|c|}{ Results } & \multirow{2}{*}{ Reference } \\
\hline & & NRR & PRR & $\mathrm{BP}$ & \\
\hline \multirow{2}{*}{ PBR } & $\mathrm{BRT}=8 \mathrm{~d}$ & 2.8 & 0.3 & 38 & \multirow{2}{*}{$\begin{array}{c}\text { González- } \\
\text { Camejo et al., } \\
2018^{\mathrm{a}}\end{array}$} \\
\hline & $\mathrm{BRT}=14 \mathrm{~d}$ & 1.6 & 0.2 & 20 & \\
\hline \multirow{2}{*}{ MPBR } & PS: Cavity pump & $6.9^{1}$ & $0.6^{2}$ & $22^{3}$ & \multirow{2}{*}{$\begin{array}{c}\text { Gómez-Gil et } \\
\text { al., } 2015\end{array}$} \\
\hline & PS: Airlift & $6.9^{1}$ & $0.6^{2}$ & $21^{3}$ & \\
\hline \multirow{2}{*}{ MPBR } & $\mathrm{BRT}=4.5 \mathrm{~d}^{\mathrm{a}}$ & 8.1 & 1.0 & 51 & \multirow{2}{*}{$\begin{array}{c}\text { Viruela et al., } \\
2018\end{array}$} \\
\hline & $\mathrm{BRT}=9 \mathrm{~d}^{\mathrm{a}}$ & 3.3 & 0.4 & 32 & \\
\hline \multirow{2}{*}{ MPBR } & $\mathrm{NPV}=27.2 \%$ & 6.6 & 0.6 & 22 & \multirow{2}{*}{$\begin{array}{c}\text { Viruela et al., } \\
2018\end{array}$} \\
\hline & $\mathrm{NPV}=13.6 \%$ & 7.6 & 1.0 & 31 & \\
\hline \multirow{3}{*}{ MPBR } & $\mathrm{HRT}=2 \mathrm{~d}^{\mathrm{b}}$ & $11.5^{4}$ & $1.4^{5}$ & $69^{6}$ & \multirow{3}{*}{$\begin{array}{c}\text { González- } \\
\text { Camejo et al., } \\
\text { 2018a }\end{array}$} \\
\hline & $\mathrm{HRT}=2.5 \mathrm{~d}^{\mathrm{b}}$ & $12.5^{4}$ & $1.5^{5}$ & $72^{6}$ & \\
\hline & $\mathrm{HRT}=3 \mathrm{~d}^{\mathrm{b}}$ & 7.5 & 1.1 & $78^{6}$ & \\
\hline
\end{tabular}

NRR: nitrogen recovery rate $\left(\mathrm{mg} \mathrm{N} \cdot \mathrm{L}^{-1} \cdot \mathrm{d}^{-1}\right)$; PRR: phosphorus recovery rate $\left(\mathrm{mg} \mathrm{P} \cdot \mathrm{L}^{-1} \cdot \mathrm{d}^{-1}\right)$; BP: biomass productivity (mg VSS $\left.\cdot \mathrm{L}^{-1} \cdot \mathrm{d}^{-1}\right)$; PBR: photobioreactor (HRT $\left.\equiv \mathrm{BRT}\right)$; MPBR: membrane photobioreactor; BRT: biomass retention time; PS: pumping system; NPV: non-photic volume; HRT: hydraulic retention time; a: HRT $=2-4$ days; b: HRT $=4.5$ days; group of numbers $(1,2,3,4,5,6)$ : non statistically significant differences.

The present work thus aimed to go one step further of the previous studies (Gómez-Gil et al., 2015; González-Camejo et al., 2018a; Viruela et al., 2018) in the optimisation of 
the outdoor operational conditions of a MPBR system, evaluating different BRT and HRT combinations to optimise the energy and nutrient recovery, photosynthetic efficiency (PE), carbon biofixation (C-BF) and membrane fouling rates (FR).

\section{Materials and methods}

\subsection{Pilot plant description}

Microalgae were cultivated in an outdoor MPBR plant $\left(39^{\circ} 30^{\prime} 04.0^{\prime}{ }^{\prime} \mathrm{N} 0^{\circ} 20^{\prime} 00.1^{\prime \prime} \mathrm{W}\right.$, Valencia, Spain), so that the solar light irradiance applied to the PBRs was variable (Table 2). It consisted of two flat-plate PBRs connected to a membrane tank (MT) (Figure 1). Each PBR had a working volume of $550 \mathrm{~L}$, and dimensions of 1.25-m high by $2-\mathrm{m}$ wide and $0.25-\mathrm{m}$ deep. Both PBRs had an additional artificial light source consisting of twelve white LED lamps (Unique Led IP65 WS-TP4S-40W-ME) installed at their back surface, which emitted a continuous light irradiance of $300 \mu \mathrm{mol} \cdot \mathrm{m}^{-2} \cdot \mathrm{s}^{-1}$ (measured on the PBRs surface). The PBRs were continuously stirred by air sparging to prevent wall fouling and ensure culture homogenisation. $\mathrm{pH}$ was kept at $7.5 \pm 0.3$ by introducing pure pressurised $\mathrm{CO}_{2}(99.9 \%)$ into the air system (Figure 1b).

The MT had a total working volume of $14 \mathrm{~L}$, which corresponded to a non-photic culture volume of $1.2 \%$. It was formed by one hollow-fibre ultrafiltration membrane bundle extracted from an industrial-scale membrane unit (PURON ${ }^{\circledR}$ Koch Membrane Systems (PUR-PSH31), $0.03 \mu \mathrm{m}$ pores). The bundle had a filtration area of $3.4 \mathrm{~m}^{2}$ and 2-m length. Air was introduced into the bottom of the MT to reduce membrane fouling by membrane scouring (Figure 1b). 

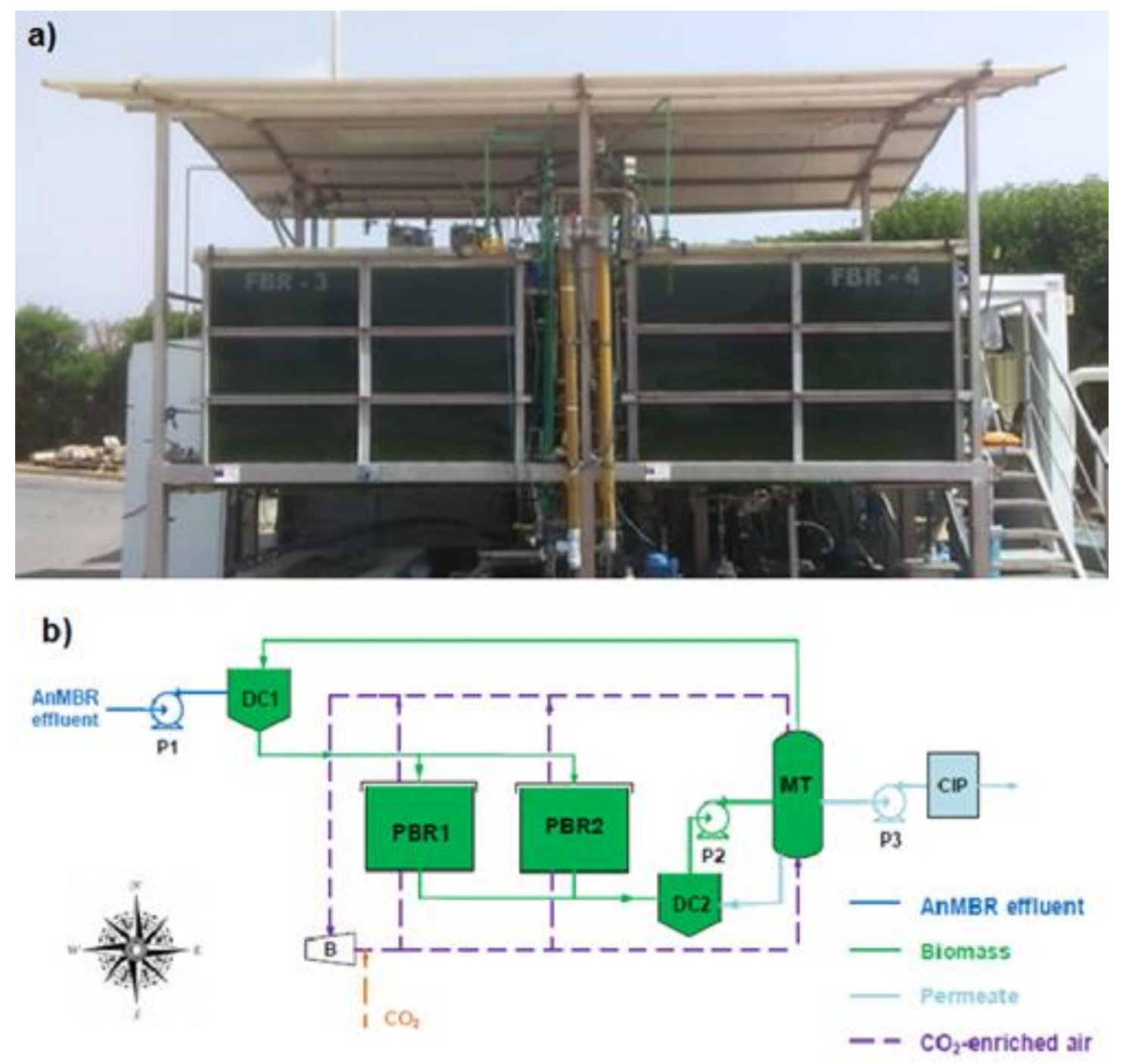

Figure 1.a) Outdoor MPBR pilot plant. b) Flow diagram of the process. PBR: photobioreactor; MT: membrane tank; P: pump; DC: distribution chamber; B: blower; CIP: clean-in-place-tank.

\subsubsection{MPBR plant operation}

To control the BRT, a given amount of microalgae biomass was wasted from the system and the cultivation substrate (anaerobically-treated sewage, see section 2.2) was fed into the system during daylight hours to replace it. To control the HRT, the corresponding amount of permeate was produced and extracted from the system as effluent during daylight hours. The filtration unit was also run during night-time for the correct 
evaluation of the filtration process performance, recycling to the system the amount of permeate that was not taken out of the MPBR plant to control the HRT. A fraction of the microalgae culture was continuously fed into the MT at a flow rate of $300 \mathrm{~L} \cdot \mathrm{h}^{-1}$. The permeate flow rate was set to around $85-102 \mathrm{~L} \cdot \mathrm{h}^{-1}$. The rejection of the membrane unit was recycled to the PBRs as shown in Figure 1b.

Membrane operation consisted of a combination of the classical stages of filtrationrelaxation $(\mathrm{F}-\mathrm{R})$ and back-flushing. Ventilation and degasification stages were also considered (Robles et al., 2013). The membrane operating mode followed a sequence of 300-s basic F-R cycle (250 s filtration and $50 \mathrm{~s}$ relaxation), $40 \mathrm{~s}$ of back-flush every 10 F-R cycles, $60 \mathrm{~s}$ of ventilation every $20 \mathrm{~F}-\mathrm{R}$ cycles and $60 \mathrm{~s}$ of degasification every 50 F-R cycles. The gross $20^{\circ} \mathrm{C}$-standardised transmembrane flux (J20) was kept around 22$30 \mathrm{LMH}(\mathrm{L} \cdot \mathrm{m}-2 \cdot \mathrm{s}-1)$. The average specific gas demand per unit of membrane area (SGDm) was kept around $0.3-0.4 \mathrm{Nm} 3 \cdot \mathrm{h}-1 \cdot \mathrm{m}-2$. This gave an average specific gas demand per volume of produced permeate (SGDP) of around 8-12 Nm3 of gas per m3 of permeate.

Further information about the instrumentation, control and automation of the MPBR plant can be found in Viruela et al. (2018).

\subsection{Microalgae substrate and inoculum}

The microalgae substrate consisted of nutrient-rich effluent from an AnMBR plant that treated real sewage, which is fully described in Giménez et al. (2011). The average characteristics of this substrate were a chemical oxygen demand (COD) concentration of $66 \pm 31 \mathrm{mg} \mathrm{COD} \cdot \mathrm{L}^{-1}$, a nitrogen concentration of $58.5 \pm 6.1 \mathrm{mg} \mathrm{N} \cdot \mathrm{L}^{-1}$ (mainly ammonium; i.e., > 95\%), a phosphorus concentration of $6.6 \pm 0.9 \mathrm{mg} \mathrm{P} \cdot \mathrm{L}^{-1}$, a sulphide concentration of $99 \pm 23 \mathrm{mg} \mathrm{S} \cdot \mathrm{L}^{-1}$ and a turbidity below $50 \mathrm{NTU}$. The AnMBR effluent 
was aerated in a regulation tank before being fed to the PBRs to completely oxidise the sulphide to sulphate, avoiding the sulphide inhibition of microalgae (González-Camejo et al., 2017).

Microalgae were obtained from the walls of the secondary clarifier in the Carraixet WWTP (Valencia, Spain) and consisted of a mixture of microalgae (including cyanobacteria), algae and bacteria (both heterotrophic and autotrophic). Prior to the inoculation in the MPBR plant, these microalgae were filtered in order to remove most of filamentous bacteria and zooplankton from the inoculum. The culture, which was mainly composed by Scenedesmus and Chlorella, was adapted to the growth medium (AnMBR effluent) under lab conditions as explained in González-Camejo et al. (2018b).

\subsection{Experimental periods}

Seven experiments were carried out in order to find the optimal operating conditions of the MPBR plant. Three of them (i.e., BRT4.5, BRT6 and BRT9) were developed at constant HRT of 2.5 days and a BRT of 4.5, 6 and 9 days, respectively. Moreover, four experiments (HRT3.5, HRT2, HRT1.5 and HRT1) were done at constant BRT of 4.5 days and at HRT of 3.5, 2, 1.5 and 1 days, respectively. The duration of each experiment varied according to the days that the culture was maintained in pseudosteady state (Table 2); i.e., when there was similar volatile suspended solids (VSS) concentration in the culture (Figures 2 and 3) and temperature was in the range of 20-30 ${ }^{\circ} \mathrm{C}$ (González-Camejo et al., 2019). 
Table 2. Operating and outdoor conditions during BRT and HRT Experiments (mean \pm standard deviation).

\begin{tabular}{ccccccc}
\hline Experiment & Days & $\begin{array}{c}\text { BRT } \\
\text { (d) }\end{array}$ & $\begin{array}{c}\text { HRT } \\
(\mathbf{d})\end{array}$ & $\begin{array}{c}\text { Solar PAR } \\
\left(\boldsymbol{\mu m o l} \cdot \mathbf{m}^{-\mathbf{2}} \cdot \mathbf{s}^{-\mathbf{1}}\right)^{*}\end{array}$ & $\begin{array}{c}\text { NLR } \\
\left(\mathbf{g ~ N} \cdot \mathbf{d}^{-\mathbf{1}}\right)\end{array}$ & $\begin{array}{c}\text { PLR } \\
\left(\mathbf{g ~ P} \cdot \mathbf{d}^{-1}\right)\end{array}$ \\
\hline BRT4.5 & 23 & 4.5 & 2.5 & $268 \pm 148$ & $27.0 \pm 3.0$ & $2.8 \pm 0.5$ \\
BRT6 & 40 & 6 & 2.5 & $319 \pm 126$ & $27.2 \pm 3.1$ & $2.6 \pm 0.7$ \\
BRT9 & 27 & 9 & 2.5 & $226 \pm 50$ & $26.8 \pm 3.7$ & $4.1 \pm 0.4$ \\
HRT3.5 & 20 & 4.5 & 3.5 & $310 \pm 57$ & $16.8 \pm 1.4$ & $2.0 \pm 0.4$ \\
HRT2 & 20 & 4.5 & 2 & $266 \pm 46$ & $34.4 \pm 4.4$ & $3.8 \pm 0.4$ \\
HRT1.5 & 13 & 4.5 & 1.5 & $318 \pm 103$ & $42.2 \pm 5.5$ & $5.0 \pm 0.8$ \\
HRT1 & 22 & 4.5 & 1 & $290 \pm 104$ & $53.1 \pm 5.7$ & $7.5 \pm 2.3$
\end{tabular}

BRT: biomass retention time; HRT: hydraulic retention time; Solar PAR: daily average solar photosynthetic active radiation; NLR: nitrogen loading rate; PLR: phosphorus loading rate.

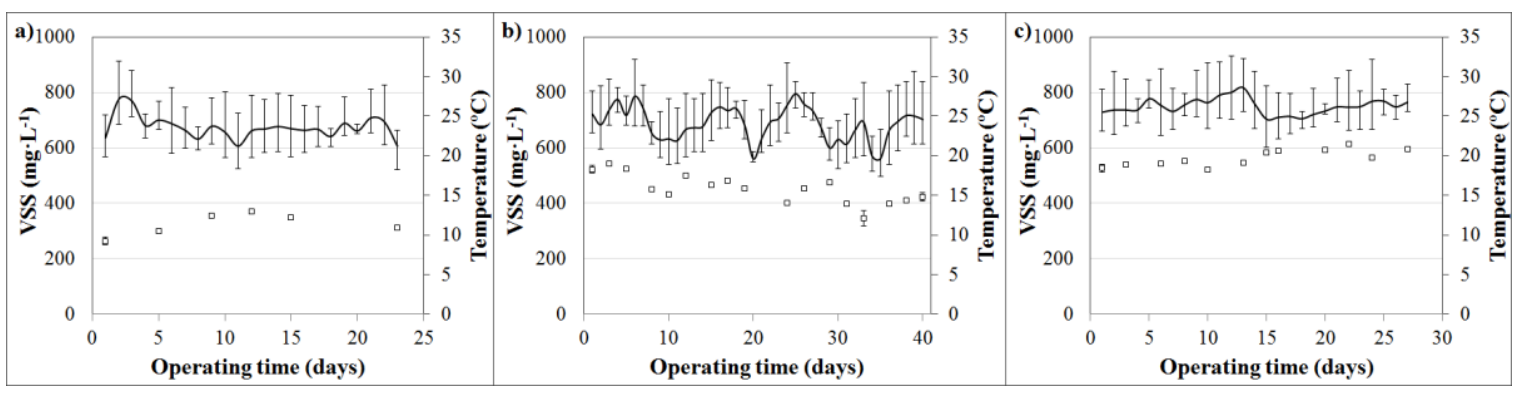

Figure 2. Evolution of the volatile suspended solids concentration $(\square)\left(\mathrm{mg} \mathrm{VSS} \cdot \mathrm{L}^{-1}\right)$ and temperature (-) $\left({ }^{\circ} \mathrm{C}\right)$ (bars indicate maximum and minimum temperatures) during BRT experiment: a) BRT4.5; b) BRT6; c) BRT9. 

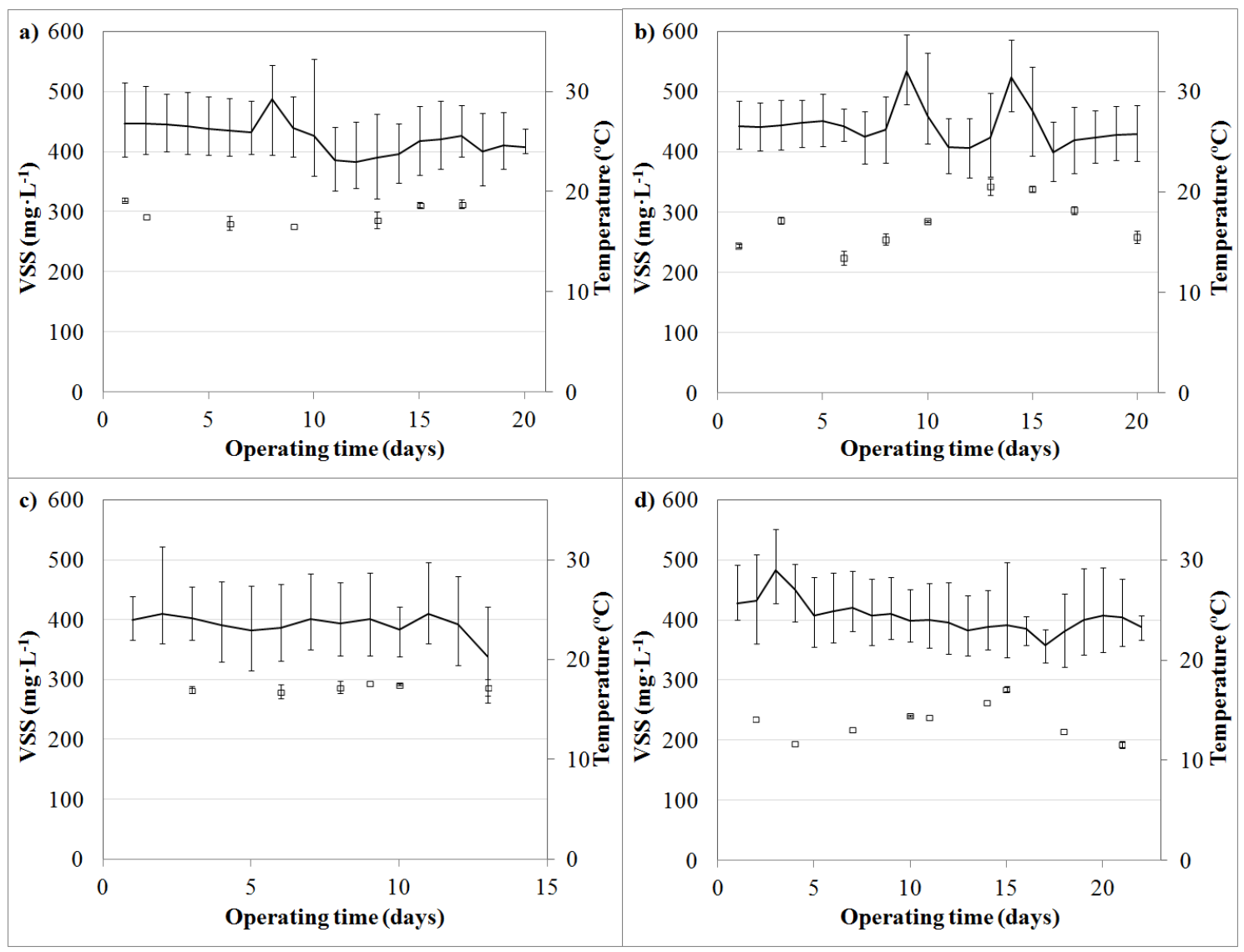

Figure 3. Evolution of the volatile suspended solids concentration ( $\square)\left(\mathrm{mg} \mathrm{VSS} \cdot \mathrm{L}^{-1}\right)$ and temperature $(-)\left({ }^{\circ} \mathrm{C}\right)$ (bars indicate maximum and minimum temperatures) during HRT experiment: a) HRT3.5; b) HRT2; c) HRT1.5; d) HRT1.

MPBR performance was evaluated under nutrient-replete conditions during the pseudosteady states of all BRT and HRT experiments; i.e., nitrogen concentrations over $10 \mathrm{mg}$ $\mathrm{N} \cdot \mathrm{L}^{-1}$ (González-Camejo et al., 2019) and phosphorus concentration in non-negligible concentrations (Figures 4 and 5). 


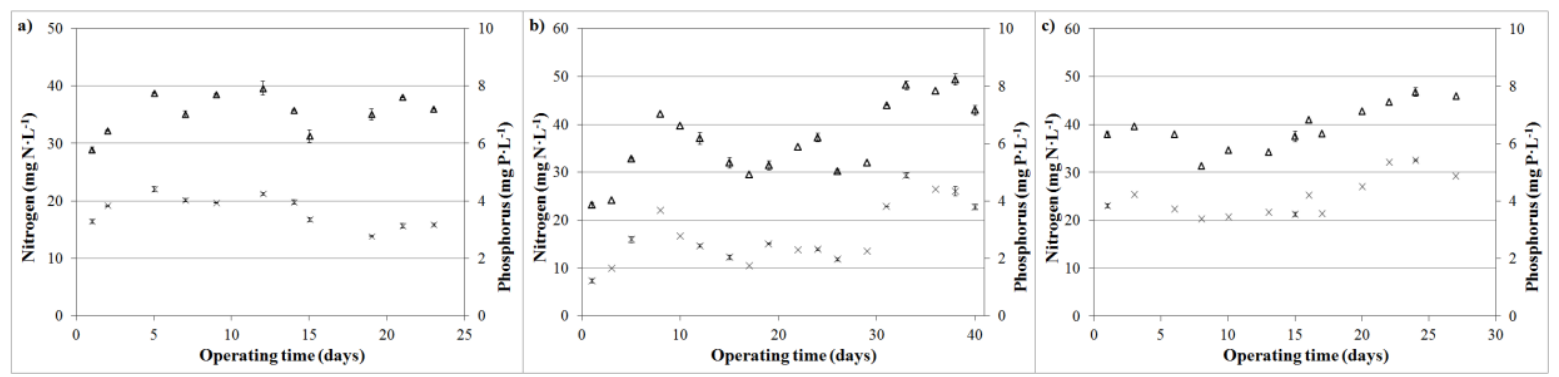

Figure 4. Evolution of the effluent nitrogen $(\Delta)\left(\mathrm{mg} \mathrm{N} \cdot \mathrm{L}^{-1}\right)$ and phosphorus $(\mathrm{x})(\mathrm{mg}$ $\mathrm{P} \cdot \mathrm{L}^{-1}$ ) concentrations in the PBRs during BRT experiments: a) BRT4.5; b) BRT6; c) BRT9
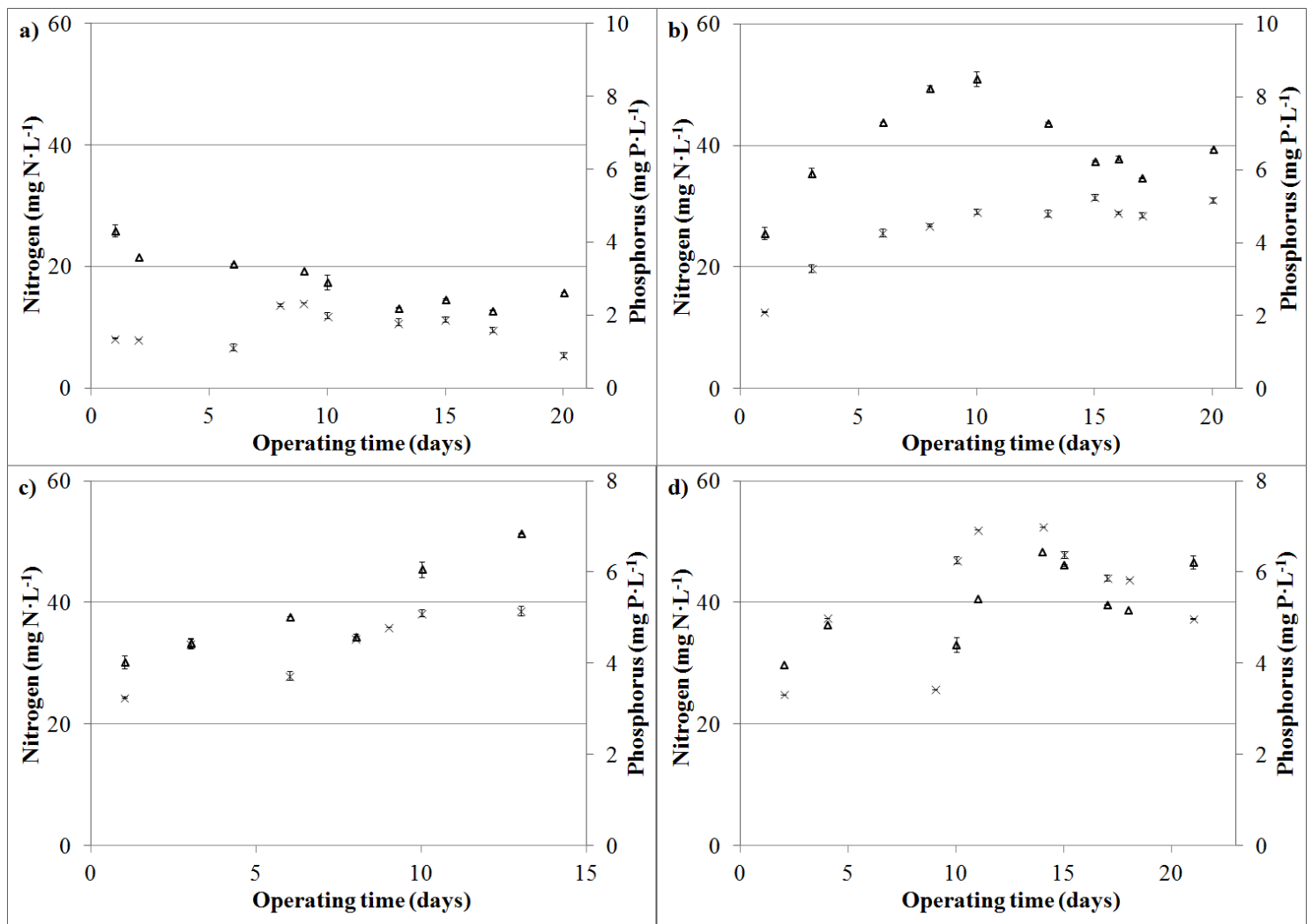

Figure 5. Evolution of the effluent nitrogen $(\Delta)\left(\mathrm{mg} \mathrm{N} \cdot \mathrm{L}^{-1}\right)$ and phosphorus $(\mathrm{x})(\mathrm{mg}$ $\mathrm{P} \cdot \mathrm{L}^{-1}$ ) concentrations in the PBRs during HRT experiment: a) HRT3.5; b) HRT2; c) HRT1.5; d) HRT1.

In order to inhibit nitrification, allylthiourea (ATU) was added to the culture to maintain a concentration of 1-5 $\mathrm{mg} \cdot \mathrm{L}^{-1}$ in the PBRs (González-Camejo et al., 2018a). In addition, 
the $\mathrm{pH}$ set-point value of the culture (7.5) made ammonia volatilisation and phosphorus precipitation be negligible (Whitton et al., 2016) so that microalgae were considered as the main responsible for nutrient recovery.

Each experiment began with a start-up phase consisting of: i) adding $10 \%$ of the working volume with the inoculum from the previous experiment and $90 \%$ of the working volume with the substrate described in Section 2.2.; ii) batch mode until reaching a biomass concentration of around $400-500 \mathrm{mg} \mathrm{VSS} \cdot \mathrm{L}^{-1}$; iii) continuous feeding to maintain the corresponding BRT and HRT (as described in section 2.1.1); and iv) reaching the pseudo-stationary state. These start-up phases were not considered in the evaluation of the MPBR performance.

Before each experiment, a chemical cleaning of the membranes was done in order to start every experiment with similar filtration conditions. The cleaning was carried out in two steps: 1) basic cleaning ( $\mathrm{pH}$ of 10.5 ) by a solution composed of $2,000 \mathrm{mg} \cdot \mathrm{L}^{-1}$ of $\mathrm{NaClO}$ for 6 hours; and 2) acid cleaning ( $\mathrm{pH}$ of 2.5) by a solution composed of 2,000 $\mathrm{mg} \cdot \mathrm{L}^{-1}$ of citric acid for 6 hours.

\subsection{Sampling, analytical methods and calculations}

Grab samples were collected in duplicate from the influent (AnMBR effluent), the culture and the effluent of the MPBR pilot plant three times a week. Ammonium $\left(\mathrm{NH}_{4}\right)$, nitrite $\left(\mathrm{NO}_{2}\right)$, nitrate $\left(\mathrm{NO}_{3}\right)$ and phosphate $\left(\mathrm{PO}_{4}\right)$ concentrations were analysed according to Standard Methods (APHA et al., 2005): Methods 4500-NH3-G, 4500NO2-B, 4500-NO3-H and 4500-P-F, respectively, in a Smartchem 200 automatic analyser (WestcoScientific Instruments, Westco). Volatile suspended solids (VSS) of the culture were analysed according to method $2540 \mathrm{E}$ of Standard Methods (APHA et al., 2005). 
The maximum quantum efficiency $\left(\mathrm{F}_{\mathrm{v}} / \mathrm{F}_{\mathrm{m}}\right)$ was measured in-situ with a portable fluorometer AquaPen-C AP-C 100 (Photon Systems Instruments). Before measuring, the samples were kept in the dark for ten minutes to become dark-adapted (Moraes et al., 2019). The turbidity of the influent was measured by a portable turbidimeter (Lovibond T3 210IR).

$50 \mu \mathrm{L}$ of culture sample were taken in duplicate twice a week to measure the total eukaryotic cells (TEC) concentration. Cells were counted by epifluorescence microscopy on a Leica DM2500 using the 100x-oil immersion lens. A minimum of 100 cells of the most abundant genus were counted with an error of less than 20\% (Pachés et al., 2012).

The presence of Escherichia coli and other coliform pathogens in the permeate was quantitatively determined through a positive $\beta$-glucorinidase assay using membrane filters, following the UNE-EN ISO 9308-1:2014 standard method.

Calculations are shown in González-Camejo et al. (2019).

\subsection{Statistical analysis}

The results obtained were statistically analysed by Statgraphics Centurion XVII. ANOVA analysis was carried out to evaluate the significance of the differences in the mean values. When p-values $<0.05$, differences were considered statistically significant.

\section{Results and discussion}

\subsection{Continuous microalgae cultivation}




\subsubsection{BRT experiments}

A significant reduction of NRR:I (p-value < 0.05) was observed with increasing BRT, from $51.7 \pm 14.3$ in Experiment BRT4.5 to $40.3 \pm 8.6 \mathrm{mg} \mathrm{N} \cdot \mathrm{mol}^{-1}$ in Experiment BRT9 (Figure 6a). The trend of photosynthetic efficiency with respect to BRT was similar to that of NRR:I, obtaining $4.4 \pm 1.6 \%$ in Experiment BRT4.5 and $3.5 \pm 0.5 \%$ in BRT9 (Figure 6c). This suggests that nitrogen recovery was related to the photosynthetic efficiency for biomass production. As for PRR:I, no significant differences were observed ( $\mathrm{p}$-value $>0.05$ ) within the evaluated BRT experiments (Figure 6b). Since phosphorus can be stored as polyphosphates (Powell et al., 2009), the phosphorus consumption by microalgae not only will depend on the operating and outdoor conditions, but also on their intracellular phosphorus reserves (Shoener et al., 2019). In terms of carbon biofixation, it was also reduced significantly ( $\mathrm{p}$-value $<0.05$ ) from 0.50 $\pm 0.05 \mathrm{~kg} \mathrm{CO} \cdot \mathrm{m}^{-3}$ influent in Experiment BRT4.5 to $0.44 \pm 0.02 \mathrm{~kg} \mathrm{CO} \cdot \mathrm{m}^{-3}$ influent in Experiment BRT9. 


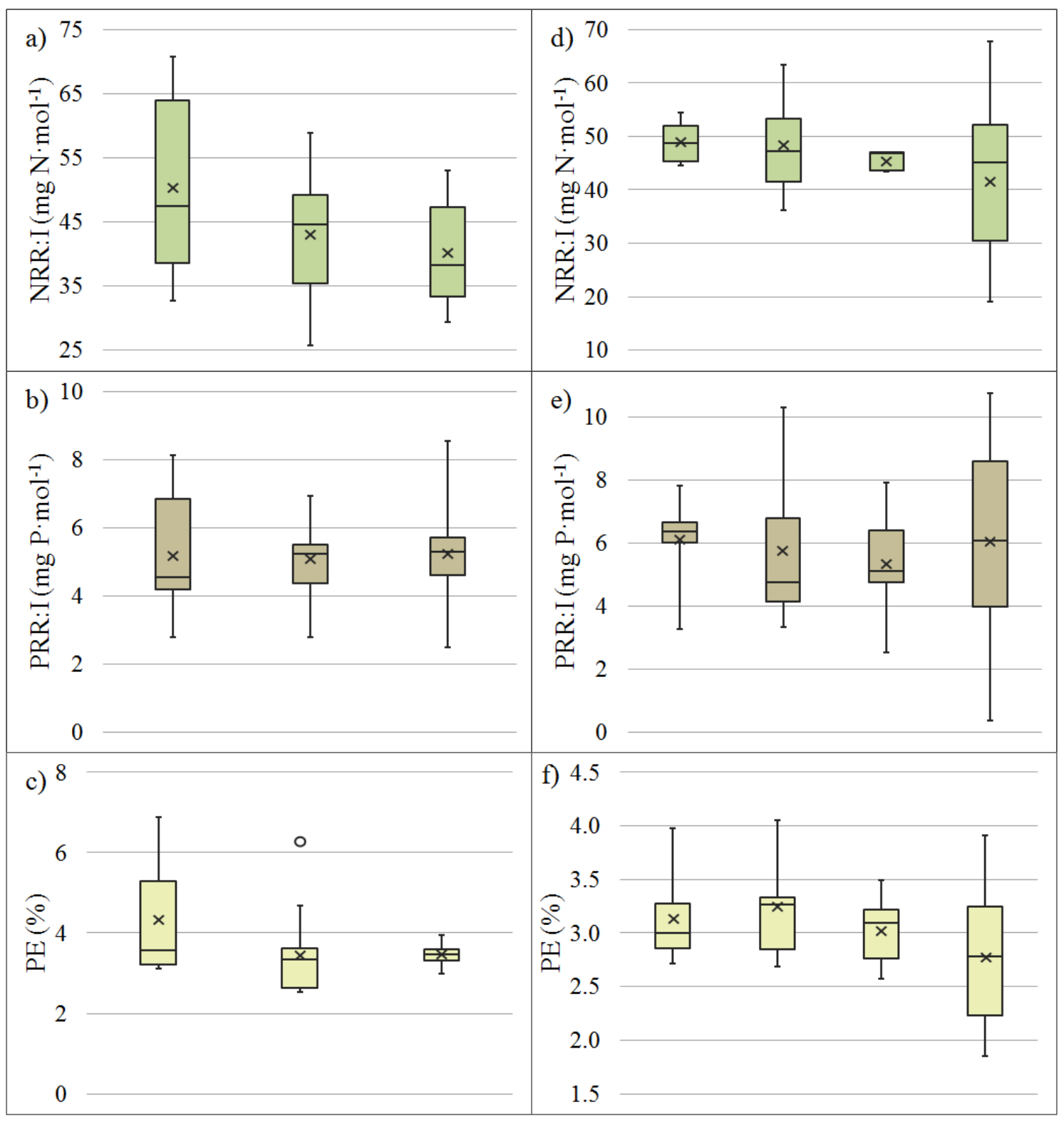

Figure 6. Box-plots of BRT experiments: a) nitrogen recovery rate:light irradiance ratio (NRR:I); b) phosphorus recovery rate:light irradiance ratio (PRR:I); and c) photosynthetic efficiency. Box-plots of HRT experiments: d) nitrogen recovery rate:light irradiance ratio (NRR:I); e) phosphorus recovery rate:light irradiance ratio (PRR:I); and f) photosynthetic efficiency.

These results therefore suggest that increasing the BRT involved a reduction in the system's performance yields, reaching the best operating conditions at 4.5 days BRT, which was close to the theoretically optimum BRT determined in batch conditions; i.e., 
4.6-5 days of BRT (González-Camejo et al., 2019). This optimum BRT is significantly lower than those reported by other authors (Table 3).

Table 3. Optimal BRTs obtained under different conditions.

\begin{tabular}{|c|c|c|c|c|}
\hline $\begin{array}{l}\text { BRT } \\
\text { (d) }\end{array}$ & Species & $\begin{array}{c}\text { Type of } \\
\text { wastewater }\end{array}$ & Type of PBR & Reference \\
\hline 4.5 & $\begin{array}{c}\text { Scenedesmus } \\
\text { dominance }\end{array}$ & $\begin{array}{l}\text { AnMBR } \\
\text { effluent }\end{array}$ & $\begin{array}{l}\text { Outdoor Flat- } \\
\text { panel MPBR }\end{array}$ & This study \\
\hline $5-10$ & $\begin{array}{c}\text { Scendesmus } \\
\text { obliquus }\end{array}$ & $\begin{array}{c}\text { Secondary } \\
\text { effluent }\end{array}$ & $\begin{array}{l}\text { Lab-scale Flat- } \\
\text { panel MPBR }\end{array}$ & $\begin{array}{l}\text { Xu et al. } \\
\text { (2015) }\end{array}$ \\
\hline $9-18$ & $\begin{array}{l}\text { Chlorella } \\
\text { vulgaris }\end{array}$ & $\begin{array}{l}\text { Synthetic } \\
\text { secondary } \\
\text { effluent }\end{array}$ & $\begin{array}{l}\text { Lab-scale Flat- } \\
\text { panel MPBR }\end{array}$ & $\begin{array}{l}\text { Luo et al. } \\
\text { (2018) }\end{array}$ \\
\hline 21 & $\begin{array}{l}\text { Chlorella } \\
\text { vulgaris }\end{array}$ & $\begin{array}{l}\text { Synthetic } \\
\text { secondary } \\
\text { effluent }\end{array}$ & $\begin{array}{l}\text { Lab-scale Flat- } \\
\text { panel MPBR }\end{array}$ & $\begin{array}{c}\text { Gao et al. } \\
\text { (2018) }\end{array}$ \\
\hline
\end{tabular}

A possible explanation for the reduced NRR:I in experiments BRT6 and BRT9 could be the higher amount of biomass concentration reached in these experiments (Figure 2). In fact, for experiments BRT4.5, BRT6 and BRT9, the VSS concentration was $326 \pm 40$, $452 \pm 53$, and $564 \pm 30 \mathrm{mg} \mathrm{VSS} \cdot \mathrm{L}^{-1}$, respectively (p-value $<0.05$ ). The higher VSS concentration reduced the light availability of microalgae (Abu-Ghosh et al., 2016), reducing the MPBR performance. However, it is striking that increasing the BRT from 4.5 to 9 days implied a reduction in NRR:I at increasing BRT, but the photosynthetic efficiency and the C-BF remained constant in Experiment BRT4.5 and BRT6. The 
worst results obtained in Experiment BRT9 were probably due to a proliferation of microorganisms other than green microalgae. In consequence, a significant amount of the biomass considered within the VSS concentration measurements did not correspond to microalgae biomass in Experiment BRT9. In fact, the TEC increased from $5.53 \cdot 10^{9} \pm$ $1.57 \cdot 10^{9}$ to $7.77 \cdot 10^{9} \pm 1.17 \cdot 10^{9}$ cells $\cdot \mathrm{L}^{-1}$ when BRT was raised from 4.5 to 6 days, respectively (p-value $<0.05$ ) but did not increase when the BRT was further extended to 9 days (TEC of $7.04 \cdot 10^{9} \pm 1.33 \cdot 10^{9}$ cells $\cdot \mathrm{L}^{-1}, \mathrm{p}$-value $>0.05$ ). In this respect, the microscopic microbiological examination revealed that the quantity of cyanobacteria, protozoans and rotifers significantly increased during Experiment BRT9, as observed under microscope (González-Camejo et al., 2019). These microorganisms are favoured at longer BRTs, when higher amounts of organic carbon are released by more severe microalgae decay (Luo et al., 2018). It must be noted that this proliferation is not convenient since these organisms can negatively affect microalgae growth. For instance, Bacillus fusiformis bacteria have been reported to be lethal to microalgae genera Chlorella and Scenedesmus (Mu et al., 2007), while the rotifer Brachionus plicatilis is able to devour up to 3000 microalgae cells per hour (Montagnes et al., 2001). With respect to cyanobacteria, Rajneesh et al. (2017) found that these microorganisms can inhibit microalgae growth by excreting toxic extracellular substances. This culture affection was indirectly measured by the maximum quantum efficiency, which is an indirect measure of the photosystem II efficiency. $F_{v} / F_{m}$ suffered a statistically significant drop from $0.70 \pm 0.04$ and $0.69 \pm 0.03$ in experiments BRT4.5 and BRT6, respectively, to $0.62 \pm 0.03$ in Experiment BRT9. According to Moraes et al. (2019), a reduction in the $\mathrm{F}_{\mathrm{v}} / \mathrm{F}_{\mathrm{m}}$ from around 0.65 to lower values is an indicator of photochemical stress of the eukaryotic algae. 
Regarding microalgae strains, in Experiment BRT4.5 Scenedesmus dominated the culture with around $95 \%$ of the TEC because the inoculum of this experiment was mainly composed of Scenedesmus (90\% of TEC). In Experiment BRT6, the culture started off dominated by Scenedesmus, but later Chlorella became dominant (85\% of TEC). Experiment BRT9 was dominated by Chlorella at around 90\% of TEC (apart from the aforementioned proliferation of cyanobacteria protozoans and rotifers). This shift in the dominance of the culture was attributed to the better acclimatisation to the effective light applied to the PBR of Chlorella in comparison with Scenedesmus. During experiments BRT6 and BRT9, the biomass concentration was significantly higher than in Experiment BRT4.5 (as already mentioned), reducing the average light intensity received by microalgae (Abu-Ghosh et al., 2016). In this respect, Chlorella have been reported to be more competitive than Scenedesmus at lower light intensities (Marcilhac et al., 2014; Sanchis-Perucho et al., 2018).

With respect to nutrient accumulation, the highest intracellular nitrogen content was reached in Experiment BRT6 $(8.5 \% \pm 1.3)$, which was operated with the highest N:P influent molar ratio $(23.4 \pm 1.8)$. On the other hand, the lowest intracellular nitrogen content $(7.4 \% \pm 0.6)$ was obtained in Experiment BRT9, which was operated with the lowest N:P influent molar ratio; i.e., $19.4 \pm 0.9$ (Table 4). This behaviour was probably due to the capacity of microalgae to modify their intracellular $\mathrm{N}: \mathrm{P}$ ratio as a consequence of fluctuating nutrient loads (Schoener et al., 2019). Tan et al. (2016) obtained similar intracellular nitrogen contents for Chlorella pyrenoidosa: $7.2-10.6 \%$, while Ruiz et al. (2014) reported 4.9-8.0\% for Scenedesmus obliquus. Regarding phosphorus, no statistically significant differences were observed ( $\mathrm{p}$-value > 0.05): 1.11.3\%. These results were within the range of those reported by Beuckels et al. (2015) for Chlorella: $0.5-1.3 \%$, and by Ruiz et al. (2014) for S. obliquus: 0.7-2.3\%. 
Table 4. Intracellular nutrient content obtained during the pseudo-stationary stages of BRT and HRT Experiments (mean \pm standard deviation).

\begin{tabular}{c|ccc|cccc}
\hline & BRT4.5 & BRT6 & BRT9 & HRT3.5 & HRT2 & HRT1.5 & HRT1 \\
Parameter & & & & & & & \\
\hline N:P & $22.2 \pm 2.4$ & $23.4 \pm 1.8$ & $19.4 \pm 0.9$ & $19.8 \pm 5.0$ & $20.6 \pm 4.8$ & $19.1 \pm 2.3$ & $14.4 \pm 3.2$ \\
influent* & & & & & & & \\
$\mathbf{N}(\%)$ & $7.8 \pm 2.5$ & $8.5 \pm 1.3$ & $7.4 \pm 0.6$ & $7.6 \pm 2.1$ & $10.4 \pm 0.6$ & $8.6 \pm 0.5$ & $5.9 \pm 2.2$ \\
$\mathbf{P}(\%)$ & $1.1 \pm 0.1$ & $1.3 \pm 0.2$ & $1.3 \pm 0.4$ & $1.2 \pm 0.1$ & $1.1 \pm 0.1$ & $1.1 \pm 0.2$ & $1.1 \pm 0.2$ \\
N:P & & & & & & & \\
culture* & $16.6 \pm 5.9$ & $15.0 \pm 3.9$ & $14.0 \pm 3.9$ & $13.4 \pm 0.8$ & $21.2 \pm 4.6$ & $17.3 \pm 5.5$ & $12.7 \pm 3.4$ \\
\hline
\end{tabular}

\subsubsection{HRT experiments}

As can be seen in Figure 6, the NRR:I and photosynthetic efficiency did not change significantly in experiments HRT3.5, HRT2, HRT1.5 (p-value > 0.05), showing NRR:I values of $49.0 \pm 4.0,48.6 \pm 9.5$ and $45.6 \pm 1.9 \mathrm{mg} \mathrm{N} \cdot \mathrm{mol}^{-1}$ and photosynthetic efficiencies of $3.1 \pm 0.5 \%, 3.2 \pm 0.4 \%$ and $3.0 \pm 0.4 \%$, respectively, for experiments HRT3.5, HRT2 and HRT1.5. However, in Experiment HRT1, the NRR:I and photosynthetic efficiency fell significantly to $41.7 \pm 14.9 \mathrm{mg} \mathrm{N} \cdot \mathrm{mol}^{-1}$ and $2.8 \pm 0.7 \%$, respectively (p-value $<0.05)$.

It must be noted that in Experiment HRT1, substrate turbidity increased from less than 50 NTU (experiments HRT3.5, HRT2 and HRT1.5) to around 200-300 NTU (Experiment HRT1). The substrate turbidity increased during Experiment HRT1 because the pre-aeration system was not able to fully oxidise the increasing sulphide load. As a result, some of the sulphides partially oxidised to elemental sulphur and was 
suspended in the substrate, increasing its turbidity. This turbidity reduced the light available for the microalgae culture, limiting microalgae growth (González-Camejo et al., 2019). Variations in both turbidity and solar PAR were probably the main responsible for the high dynamics of the data measured in Experiment HRT1, as displayed in the box-plots of HRT experiments (Figure 6). When the substrate presented high values of turbidity and low solar PAR, the average irradiance inside the culture was thus low and vice versa, decreasing or increasing the microalgae performance.

Similarly to BRT experiments, PRR:I showed no significant differences in HRT experiments (Figure 6e). In conclusion, HRT did not have a direct influence on either nutrient recovery or photosynthetic efficiency under nutrient-replete conditions and quite stable temperatures as in this case (González-Camejo et al., 2019).

According to the results of HRT experiments, the appropriate treatment of the AnMBR effluent for sensitive areas which accounts for $15 \mathrm{mg} \mathrm{N} \cdot \mathrm{L}^{-1}$ and $2 \mathrm{mg} \mathrm{P} \cdot \mathrm{L}^{-1}$ for a WWTP between 10,000-100,000 population equivalent (p.e.) (Council Directive 91/271/CEE) was only achieved with the operating conditions of Experiment HRT3.5. On the other hand, effluent nutrient concentrations in the rest of the experiments were far above the legal limits (Figure 5). Hence, the optimum HRT of the system will depend on the nutrient loads. HRTs shorter than the optimum would mean that the microalgae would not have enough time to absorb the nutrients from the substrate, reaching an effluent nutrient concentration close to that of the influent, while excessively long HRTs would make the system nutrient-limited. In addition, C-BF was the highest in Experiment HRT3.5, i.e., $0.55 \pm 0.05 \mathrm{~kg} \mathrm{CO} \cdot \mathrm{m}^{-3}$ influent. For the rest of HRT experiments, the C-BF was $0.32 \pm 0.06 \mathrm{~kg} \mathrm{CO} \cdot \mathrm{m}^{-3}$ influent (Experiment HRT2); $0.25 \pm 0.03 \mathrm{~kg} \mathrm{CO} \cdot \mathrm{m}^{-3}$ influent (Experiment HRT1.5); and $0.14 \pm 0.02 \mathrm{~kg} \mathrm{CO} \cdot \mathrm{m}^{-3}{ }_{\text {influent }}$ (Experiment HRT1). 
Consequently, the optimum HRT in the operated outdoor conditions was considered to be 3.5 days. If the microalgae obtained in Experiment HRT3.5 were anaerobically digested, energy recovery from microalgae biomass could reach up to $0.443 \mathrm{kWh} \cdot \mathrm{m}^{-}$ ${ }^{3}{ }_{\text {influent. In comparison with other PBR configurations such as the tubular PBRs operated }}$ by García et al. (2018), a reduction of the operating HRT would be achieved in the present study, from 5 to 3.5 days, which would imply a reduction of $30 \%$ of the working volume. The results obtained in this study are therefore promising, but the efficiency of the system must be further increased to operate it at lower HRTs. This would imply the reduction of the wastewater treatment footprint, which is one of the major drawbacks of microalgae-based systems (Acién et al., 2016).

Unlike BRT experiments, in HRT experiments, no shift in the dominating microalgae genera of the culture was observed and the culture was mainly composed of Chlorella (> 95\% of TEC) in all HRT experiments. The dominance of this genus in the inoculum of Experiment HRT3.5 was hypothesised to have an influence on the high percentage of this strain during the HRT experiments.

As in BRT experiments, the nitrogen content of the biomass generated during HRT experiments increased with the N:P influent molar ratio (Table 4), and the intracellular nitrogen content varied in the range of $5.9-10.4 \%$, in agreement with the values obtained by Beuckels et al. (2015) for Chlorella: 5.0-10.1\%. No significant differences were observed regarding intracellular phosphorus content, resulting in values similar to those obtained in BRT experiments: 1.1-1.2\%.

It must be highlighted that the values obtained in this study for the photosynthetic efficiency; i.e. (in the range of 3.0-4.4\%, see Figure 6) are quite higher than those obtained by Romero-Villegas et al. (2018) in outdoor flat-panel PBRs (2.8\%); although they were considerably lower than the $7.4 \%$ reported by Alcántara et al. (2013) in lab 
conditions. Further research is therefore required to improve the microalgae photosynthetic efficiency in this MPBR plant in order to achieve its maximum potential.

\subsection{Membrane filtration}

To fully assess the feasibility of MPBR technology, it is necessary to evaluate the behaviour of the membrane filtration during the continuous operation of the MPBR plant.

During Experiment BRT4.5, fouling rate remained low (below $5 \mathrm{mbar} \cdot \mathrm{min}^{-1}$ ) for almost 18 days, but it rose sharply up to $25 \mathrm{mbar} \cdot \mathrm{min}^{-1}$ at day 21 (Figure 7a). Experiment BRT6 (VSS concentration of $452 \pm 53 \mathrm{mg}$ VSS $\cdot \mathrm{L}^{-1}$ ) started with similar operating filtration conditions (i.e., $\mathrm{J}_{20}$ and $\mathrm{SGD}_{\mathrm{p}}$ ) as BRT4.5 (Figure $7 \mathrm{~b}$ ) but at higher VSS concentration: $326 \pm 40 \mathrm{mg} \mathrm{VSS} \cdot \mathrm{L}^{-1}$ (Figure 2). However, this increase in microalgae biomass did not seem to significantly affect the membrane performance since the evolution of the fouling rate at the beginning of both experiments BRT4.5 and BRT6 were similar (Figure 7).

At day 18 of Experiment BRT6, fouling rate exceeded the value of $5 \mathrm{mbar} \cdot \mathrm{min}^{-1}$ and the $\mathrm{SGD}_{\mathrm{p}}$ was doubled at day 22 to verify whether fouling rate could be reduced. Figure $7 \mathrm{~b}$ shows that fouling remained stable around $7-10 \mathrm{mbar} \cdot \mathrm{min}^{-1}$ for 10 additional days (until day 32 of Experiment BRT6). However, fouling rate surged up to $35 \mathrm{mbar} \cdot \mathrm{min}^{-1}$ at day 37 of Experiment BRT6 (Figure 7), indicating a significant membrane fouling propensity under the evaluated operating conditions. Experiment BRT9 showed a sharp increase in fouling rate after 7 days of operation, indicating a higher membrane fouling propensity, even though $\mathrm{J}_{20}$ was slightly lower than in experiments BRT4.5 and BRT6 (Figure 7c). This higher fouling propensity could be attributed not only to the increased VSS concentration (Figure 2) but also to the aforementioned proliferation of 
filamentous microorganisms such as cyanobacteria (section 3.1.1). In fact, membrane filtration has been reported to worsen as contamination by microzooplankton increases (Wang et al., 2019). Hence, operating at a BRT of 9 days was not only detrimental for the MPBR performance in terms of nutrient recovery (section 3.1.1), but also for the membrane operation.

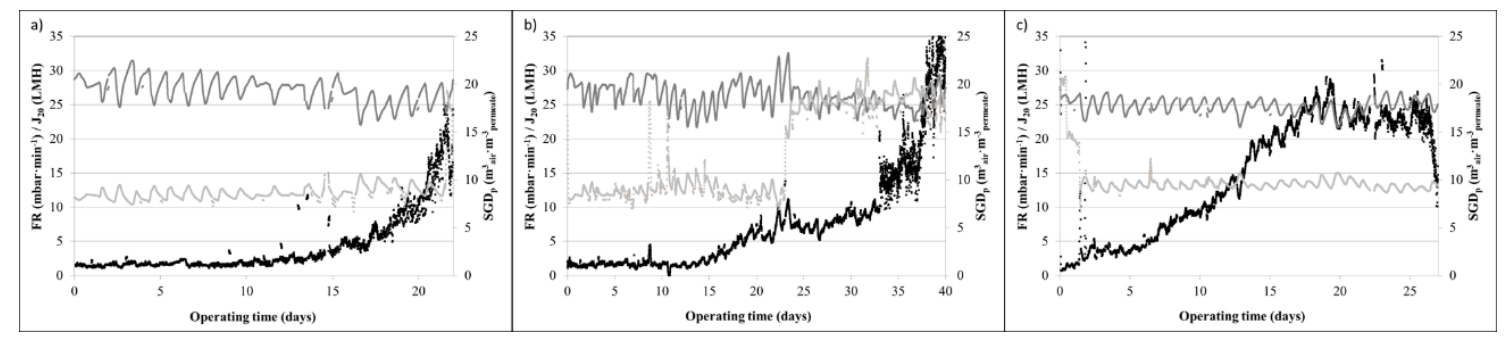

Figure 7. Membrane filtration performance at the pilot plant. Fouling rate (一) $\left(\mathrm{mbar} \cdot \mathrm{min}^{-1}\right), \mathrm{J}_{20}(-)(\mathrm{LMH})$ and $\mathrm{SGD}_{\mathrm{p}}(-)\left(\mathrm{m}^{3}\right.$ air $\cdot \mathrm{m}^{-3}$ permeate $)$ for: a) BRT4.5; b) BRT6; c) BRT9.

Figure 8 shows that there were no significant differences in fouling rates during the performance of the membrane unit in HRT experiments. The operating conditions and VSS concentrations during these experiments remained practically stable (see Figure 8 and Figure 3).

It should be noted that it was possible to remove most of the fouling from the membrane surface by intensive physical cleaning procedures, mainly based on back-flushing. However, in order to obtain comparable conditions with the next experiment in terms of filtration performance, additional chemical cleaning was carried out to ensure the membranes recovered their filtration capacity before starting a new experiment. It is also important to note that this chemical cleaning frequency is regarded as excessive since it has a negative effect on the membrane lifespan and increases operating and maintenance costs (Zhang and $\mathrm{Fu}, 2018$ ). 


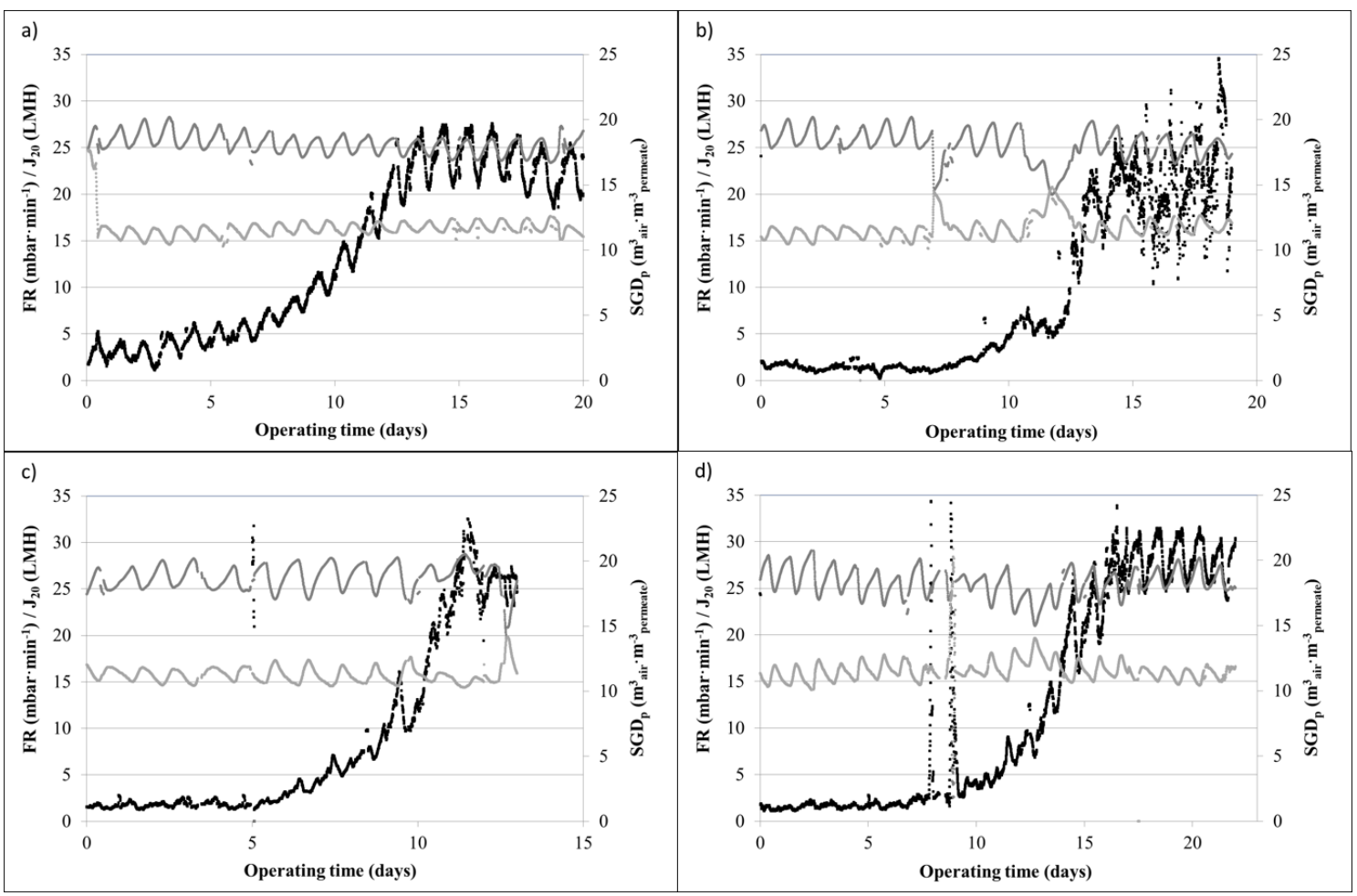

Figure 8. Membrane filtration performance at the pilot plant. Fouling rate (-) $\left(\mathrm{mbar} \cdot \mathrm{min}^{-1}\right), \mathrm{J}_{20}(-)(\mathrm{LMH})$ and $\mathrm{SGD}_{\mathrm{p}}(-)\left(\mathrm{m}^{3}\right.$ air $\cdot \mathrm{m}^{-3}$ permeate $)$ for: a) HRT3.5; b) HRT2; c) HRT1.5; d) HRT1

Overall, the system was operated at high $\mathbf{J}_{20}(22-30 \mathrm{LMH})$ during the experiments by applying fairly low $\mathrm{SGD}_{\mathrm{p}}\left(8-12 \mathrm{Nm}^{3}\right.$ air $\mathrm{m}^{-3}$ permeate, excluding second half of Experiment BRT6), which highlights the potential of membrane filtration for microalgae cultivation in MPBRs. For example, $\mathrm{SGD}_{\mathrm{p}}$ of 15.4 and $16.5 \mathrm{~m}^{3}$ air $\mathrm{m}^{-3}$ permeate have been reported by Judd \& Judd (2011) for treating municipal and industrial wastewater, respectively, corresponding to an $\mathrm{SGD}_{\mathrm{m}}$ of 0.30 and $0.23 \mathrm{~m}^{3}$ air $\cdot \mathrm{h}^{-1} \cdot \mathrm{m}^{-2}$ and $\mathrm{J}_{20}$ of 19.5 and $15.4 \mathrm{LMH}$, respectively. The operating costs associated with air sparging in the membrane tank are thus expected to be low when operating at optimised membrane performance.

Neither E.coli cfu per $100 \mathrm{~mL}$ nor helminthic eggs were detected in the final treated water. A source of reclaimed water can therefore be produced by this MPBR technology for irrigation or different urban and industrial purposes. It is important to note that there 
is a need to move towards feasible treatment solutions aimed at producing reclaimed water to help to alleviate the water scarcity problems related to hydric stress.

\section{Conclusions}

Maximum NRR:I ratios, photosynthetic efficiencies and carbon biofixations were obtained at BRT of 4.5 days, worsening the MPBR performance at longer BRT.

Regarding HRTs, similar results in terms of photosynthetic efficiencies, NRR:I and PRR:I ratios were observed for HRTs of 3.5, 2 and 1.5 days under non-nutrient-limited conditions. However, microalgae performance worsened at HRT of 1 day due to a reduction of light availability of the culture. Maximum values of $\mathrm{C}-\mathrm{BF}(0.55 \pm 0.05 \mathrm{~kg}$ $\mathrm{CO}_{2} \cdot \mathrm{m}^{-3}$ influent) were achieved in Experiment HRT3.5, which was considered the optimum HRT.

Fouling rate increased when operating at the longest BRT (9 days), mainly due to higher biomass concentrations and the proliferation of filamentous organisms in the culture. In contrast, it remained similar when the HRT was ranged from 1 to 3.5 days.

MPBR technology could be considered a source of reclaimed water since no pathogens were found in the permeate. Moreover, the combination of MPBR and anaerobic digestion technology could recover up to $0.443 \mathrm{kWh}$ per $\mathrm{m}^{3}$ influent from microalgae biomass.

\section{Acknowledgements}

This research work was supported by the Spanish Ministry of Economy and Competitiveness (MINECO, Projects CTM2014-54980-C2-1-R and CTM2014-54980C2-2-R) jointly with the European Regional Development Fund (ERDF), which are gratefully acknowledged. It also received support from the Spanish Ministry of 
Education, Culture and Sport via a pre-doctoral FPU fellowship to the first author (FPU14/05082).

\section{References}

1. Abu-Ghosh, S., Fixler, D., Dubinsky, Z., Iluz, D., 2016. Flashing light in microalgae biotechnology. $\quad$ Bioresour. $\quad$ Technol. 357-363. http://dx.doi.org/10.1016/j.biortech.2015.12.057

2. Acién, F.G., Gómez-Serrano, C., Morales-Amaral, M.M., Fernández-Sevilla, J.M., Molina-Grima E., 2016. Wastewater treatment using microalgae: how realistic a contribution might it be to significant urban wastewater treatment? Appl. Microbiol. Biotechnol. 100, 9013-9022. http://dx.doi.org/10.1007/s00253-016-7835-7

3. Alcántara, C., García-Encina, P.A., Muñoz, R., 2013. Evaluation of mass and energy balances in the integrated microalgae growth-anaerobic digestion process. Chem. Eng. J. 221, 238-246. http://dx.doi.org/10.1016/j.cej.2013.01.100

4. APHA-AWWA-WPCF, 2005. Standard methods for the examination of water and wastewater, 21st edition. American Public Health Association, American Water Works Association, Water Pollution Control Federation. Washington DC, USA.

5. Bilad, M.R., Discart, V., Vandamme, D., Foubert, I., Muylaert, K., Vankelecom, I.F.J., 2014. Coupled cultivation and pre-harvesting of microalgae in a membrane photobioreactor (MPBR). Bioresour Technol. 155, 410-417. http://dx.doi.org/10.1016/j.biortech.2013.05.026

6. Beuckels, A., Smolders, E. Muylaert, K., 2015. Nitrogen availability influences phosphorus removal in microalgae-based wastewater Treatment. Water Res. 77, 98106. http://dx.doi.org/10.1016/j.watres.2015.03.018 
7. Council Directive 91/271/EEC of 21 May 1991 concerning urban waste-water treatment, OJ L 135, 30.5.1991, p. 40-52.

8. Foladori, P., Petrini, S., Andreottola, G., 2018. Evolution of real municipal wastewater treatment in photobioreactors and microalgae-bacteria consortia using real-time parameters, Chem. Eng. J. 345, 507-516. https://doi.org/10.1016/j.cej.2018.03.178

9. Gao, F., Cui, W., Xu, J.P., Li, C., Jin, W.H., Yang H.L., 2019. Lipid accumulation properties of Chlorella vulgaris and Scenedesmus obliquus in membrane photobioreactor (MPBR) fed with secondary effluent from municipal wastewater treatment plant. Renewable Energy 136, 671-676. https://doi.org/10.1016/j.renene.2019.01.038

10. Gao, F., Penga, Y.Y., Lia, C., Cuia, W., Yang, Z.H., Zeng, G.M., 2018. Coupled nutrient removal from secondary effluent and algal biomass production in membrane photobioreactor (MPBR): Effect of HRT and long-term operation. Chem. Eng. J. 335, 169-175. http://dx.doi.org/10.1016/j.cej.2017.10.151

11. García, J., Ortiz, A., Álvarez, E., Belohlav, V., García-Galán, M.J., DíezMontero, R., Álvarez, J.A., Uggetti, E., 2018. Nutrient removal from agricultural run-off in demonstrative full scale tubular photobioreactors for microalgae growth. Ecological Eng. 120, 513-521. https://doi.org/10.1016/j.ecoleng.2018.07.002

12. Giménez, J.B., Robles, A., Carretero, L., Durán, F., Ruano, M.V., Gatti, M.N., Ribes, J., Ferrer, J., Seco, A., 2011. Experimental study of the anaerobic urban wastewater treatment in a submerged hollow-fibre membrane bioreactor at pilot $\begin{array}{llll}\text { scale. } & \text { Bioresour. } & \text { Technol. } & \text { 8799-8806. }\end{array}$ https://doi.org/10.1016/j.biortech.2011.07.014 
13. Gómez-Gil, T., Viruela, A., Murgui, M., Durán, F., Robles, A., Ruano, M.V., Barat, R., Seco, A., Ferrer, J., 2015. Design/operating Factors Affecting The Performane Of An Outdoor MPBR for Tertiary Sewage Treatment. IWA Specialist Conference on Nutrient Removal and Recovery 2015. 18-21 May 2015. Gdansk, Poland.

14. Gonçalves, A.L., Pires, J.C.M., Simões, M., 2017. A review on the use of microalgal consortia for wastewater treatment, Algal Res. 24, 403-415. http://dx.doi.org/10.1016/j.algal.2016.11.008

15. Gong, H., Jin Z., Xu H., Yuan Q., Zuo J., Wu J., Wang K., 2019. Enhanced membrane-based pre-concentration improves wastewater organic matter recovery: Pilot-scale performance and membrane fouling. J. Clean. Prod. 206, 307-314. https://doi.org/10.1016/j.jclepro.2018.09.209

16. Gonzalez-Camejo, J., Jiménez-Benítez, A., Ruano, M.V., Robles, A., Barat, R., Ferrer, J., 2019. Preliminary tests to optimise the performance of an outdoor membrane photobioreactor. J. Environ. Manag. Data in brief (submitted).

17. Gonzalez-Camejo, J., Barat, R., Ruano, M.V., Seco, A., Ferrer, J., 2018a. Outdoor flat-panel membrane photobioreactor to treat the effluent of an anaerobic membrane bioreactor. Influence of operating, design and environmental conditions. Water Sci. Technol. 78(1) 195-206. http://dx.doi.org/10.2166/wst.2018.259

18. González-Camejo, J., Barat, R., Pachés, M., Murgui, M., Ferrer, J., Seco, A., 2018b. Wastewater Nutrient Removal in a Mixed Microalgae-bacteria Culture: Effect of Light and Temperature on the Microalgae-bacteria Competition. Environ. Technol. 39(4), 503-515. http://dx.doi.org/10.1080/09593330.2017.1305001.

19. González-Camejo, J., Serna-García, R., Viruela, A., Pachés, M., Durán, F., Robles, A., Ruano, M.V., Barat R., Seco, A., 2017. Short and long-term experiments 
on the effect of sulphide on microalgae cultivation in tertiary sewage treatment. Bioresour. Technol. 244, 15-22. http://dx.doi.org/10.1016/j.biortech.2017.07.126

20. Guldhe, A., Kumari, S., Ramanna, L., Ramsundar, P., Singh, P., Rawat, I., Bux, F., 2017. Prospects, recent advancements and challenges of different wastewater streams for microalgal cultivation. J. Environ. Manag. 203, 299-315. http://dx.doi.org/10.1016/j.jenvman.2017.08.012

21. Judd, S., Judd, C., 2011. The MBR Book: Principles and Applications of Membrane Bioreactors in Water and Wastewater Treatment, 2nd Edition. Elsevier. ISBN: 978-0-08-096682-3.

25. Luo, Y., Le-Clech, P., Henderson, R.K., 2018. Assessment of membrane photobioreactor (MPBR) performance parameters and operating conditions. Water Res. 138, 169-180. https://doi.org/10.1016/j.watres.2018.03.050

26. Marcilhac, C., Sialve B., Pourcher A.M., Ziebal C., Bernet N., Béline F., 2014. Digestate color and light intensity affect nutrient removal and competition phenomena in a microalgal-bacterial ecosystem, Water Res. 64, 278-287. http://dx.doi.org/10.1016/j.watres.2014.07.012

27. Montagnes, D.J.S., Kimmance, S.A., Tsounis, G., Gumbs, J.C., 2001. Combined effect of temperature and food concentration on the grazing rate of the rotifer Brachionus plicatilis. Mar. $\quad$ Biol. $\quad$ 139, 975-979. https://doi.org/10.1007/s002270100632

28. Moraes, L., Martins, G., Morillas, A., Oliveira, L., Greque, M., Molina-Grima, E., Vieira, J.A., Acién, F.G., 2019. Engineering strategies for the enhancement of Nannochloropsis gaditana outdoor production: influence of the $\mathrm{CO} 2$ flow rate on the culture performance in tubular photobioreactors. Process Biochemistry 76, 171-177. https://doi.org/10.1016/j.procbio.2018.10.010 
29. Mu, R.M., Fan, Z.Q., Pei, H.Y., Yuan, X.L., Liu, S.X., Wang, X.R., 2007. Isolation and algae lysing characteristics of the algicidal bacterium B5. J. Environ. Sci. 19, 1336-1340. https://doi.org/10.1016/S1001-0742(07)60218-6

30. Nayak, M., Dhanarajan, G., Dineshkumar, R., Sen, R., 2018. Artificial intelligence driven process optimization for cleaner production of biomass with covalorization of wastewater and flue gas in an algal biorefinery. J. Clean. Prod. 201, 1092-1100. https://doi.org/10.1016/j.jclepro.2018.08.048

31. Pachés, M., Romero, I., Hermosilla, Z. and Martinez-Guijarro, R. 2012. PHYMED: An ecological classification system for the Water Framework Directive based on phytoplankton community composition. Ecological Indicators 19, 15-23. https://doi.org/10.1016/j.ecolind.2011.07.003

32. Powell, N., Shilton, A., Chisti, Y., Pratt, S., 2009. Towards a luxury uptake process via microalgae - Defining the polyphosphate dynamics. Water Res. 43, 4207-4213. https://doi:10.1016/j.watres.2009.06.011

33. Porcelli N., Judd S., 2010. Chemical cleaning of potable water membranes: a review, Sep. $\quad$ Purif. $\quad$ Technol. https://doi.org/10.1016/j.seppur.2009.12.007

34. Rajneesh, Singh, S. P., Pathak, J., Sinha, R.P., 2017. Cyanobacterial factories for the production of green energy and value-added products: An integrated approach for economic viability. Renewable and Sustainable Energy Reviews 69, 578-595. https://doi.org/10.1016/j.rser.2016.11.110

35. Robles, A., Ruano, M.V., Ribes, J., Ferrer, J., 2013. Factors that affect the permeability of commercial hollow-fibre membranes in a submerged anaerobic MBR $\begin{array}{llll}\text { (HF-SAnMBR) } \quad \text { system. } & \text { Water } \quad \text { Res. } & \text { 47, } & \end{array}$ http://dx.doi.org/10.1016/j.watres.2012.11.055 
36. Romero-Villegas, G.I., Fiamengo, M., Acién-Fernández, F.G., Molina-Grima, E., 2018. Utilization of centrate for the outdoor production of marine microalgae at the pilot-scale in raceway photobioreactors, J. Environ. Manag. 228, 506-516. https://doi.org/10.1016/j.jenvman.2018.08.020

37. Ruiz, J., Arbib, Z., Álvarez-Díaz, P.D., Garrido-Pérez, C., Barragán, J., Perales, J.A., 2014. Influence of light presence and biomass concentration on nutrient kinetic removal from urban wastewater by Scenedesmus obliquus. Journal of Biotechnology, 178, 32-37. http://dx.doi.org/10.1016/j.jbiotec.2014.03.001

38. Sanchis-Perucho, P., Duran, F., Barat, R., Pachés, M., Aguado, D., 2018. Microalgae population dynamics growth with AnMBR effluent: effect of light and phosphorous concentration, Water Sci. Technol. 77(11-12) (2018) 2566-2577. http://dx.doi.org/10.2166/wst.2018.207

39. Seco, A., Aparicio, S., González-Camejo, J., Jiménez-Benítez, A., Mateo, O., Mora, J.F., Noriega-Hevia, G., Sanchis-Perucho, P., Serna-García, R., ZamoranoLópez, N., Giménez, J.B., Ruiz-Martinez, A., Aguado, D., Barat, R., Borrás, L., Bouzas, A., Martí, N., Pachés, M., Ribes, J., Robles, A., Ruano, M.V., Serralta, J. and Ferrer, J., 2018. Resource recovery from sulphate-rich sewage through an innovative anaerobic-based water resource recovery facility (WRRF). Water Science and Technology 78 (9), 1925-1936. https://doi.org/10.2166/wst.2018.492

40. Shoener, B.D., Schramm, S.M., Béline, F., Bernard, O., Martínez, C., Plósz, B.G., Snowling, S., Steyer, J.P., Valverde-Pérez, B., Wágner, D., Guest, J.S., 2019. Microalgae and cyanobacteria modeling in water resource recovery facilities: A

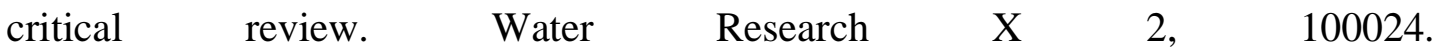
https://doi.org/10.1016/j.wroa.2018.100024 
41. Tan, X.B., Zhang, Y.L., Yang, L.B., Chu, H.Q., Guo, J., 2016. Outdoor cultures of Chlorella pyrenoidosa in the effluent of anaerobically digested activated sludge: The effects of $\mathrm{pH}$ and free ammonia. Bioresour. Technol. 200, 606-615. http://dx.doi.org/10.1016/j.biortech.2015.10.095

42. Udaiyappan, A.F.M., Hasan, H.A., Takriff, M.S., Abdullah, S.R.S, 2017. A review of the potentials, challenges and current status of microalgae biomass applications in industrial wastewater treatment. Journal of Water Process Engineering 20, 8-21. http://dx.doi.org/10.1016/j.jwpe.2017.09.006

43. UNE EN ISO 9308-1:2014, AENOR, 2014. Water Quality - Enumeration of Escherichia Coli And Coliform Bacteria - Part 1: Membrane Filtration Method For Waters With Low Bacterial Background Flora (Iso 9308-1:2014/Amd 1:2016), Asociación Española de Normalización (AENOR).

44. Van Den Hende, S., Beelen V., Bore G., Boon N., Vervaeren H., 2014. Upscaling aquaculture wastewater treatment by microalgal bacterial flocs: From lab reactors to an outdoor raceway pond. Bioresour. Technol. 159 (2014) 342-354. http://dx.doi.org/10.1016/j.biortech.2014.02.113

45. Viruela A., Robles A., Durán F., Ruano M.V., Barat R., Ferrer J., Seco A., 2018. Performance of an outdoor membrane photobioreactor for resource recovery from anaerobically treated sewage. J. Clean. Prod. 178, 665-674. https://doi.org/10.1016/j.jclepro.2017.12.223

46. Wang, L., Pan, B., Gao, Y., Li, C., Ye, J., Yang, L., Chen, Y., Hu, Q., Zhang, X., 2019. Efficient Membrane Microalgal Harvesting: Pilot-scale Performance and Technoeconomic Analysis. J. Clean. Prod. 218, 83-95. https://doi.org/10.1016/j.jclepro.2019.01.321 
47. Whitton, R., Le Mével, A., Pidou, M., Ometto, F., Villa, R., Jefferson, B., 2016. Influence of microalgal $\mathrm{N}$ and $\mathrm{P}$ composition on wastewater nutrient remediation. Water Res. 91, 371-378. https://doi.org/10.1016/j.watres.2015.12.054

48. Xu, M., Li, P., Tang, T., Hu, Z., 2015. Roles of SRT and HRT of an algal membrane bioreactor system with a tanks-in-series configuration for secondary wastewater effluent polishing. Ecol. Eng. 85, 257-264. http://dx.doi.org/10.1016/j.ecoleng.2015.09.064

49. Zhang, Y., Fu, Q., 2018. Algal fouling of microfiltration and ultrafiltration membranes and control strategies: A review. Separation and Purification Technology 203, 193-208. https://doi.org/10.1016/j.seppur.2018.04.040 